\title{
A psychometric evaluation of the career decision making self-efficacy scale
}

\author{
Chandra Yudistira Purnama*; Linda Ernawati \\ Universitas Jenderal Achmad Yani \\ Jl. Terusan Jenderal Sudirman, Cibeber, Cimahi Selatan, Kota Cimahi, Jawa Barat 40531, Indonesia \\ *Corresponding Author. E-mail: chandra.yudistira@lecture.unjani.ac.id
}

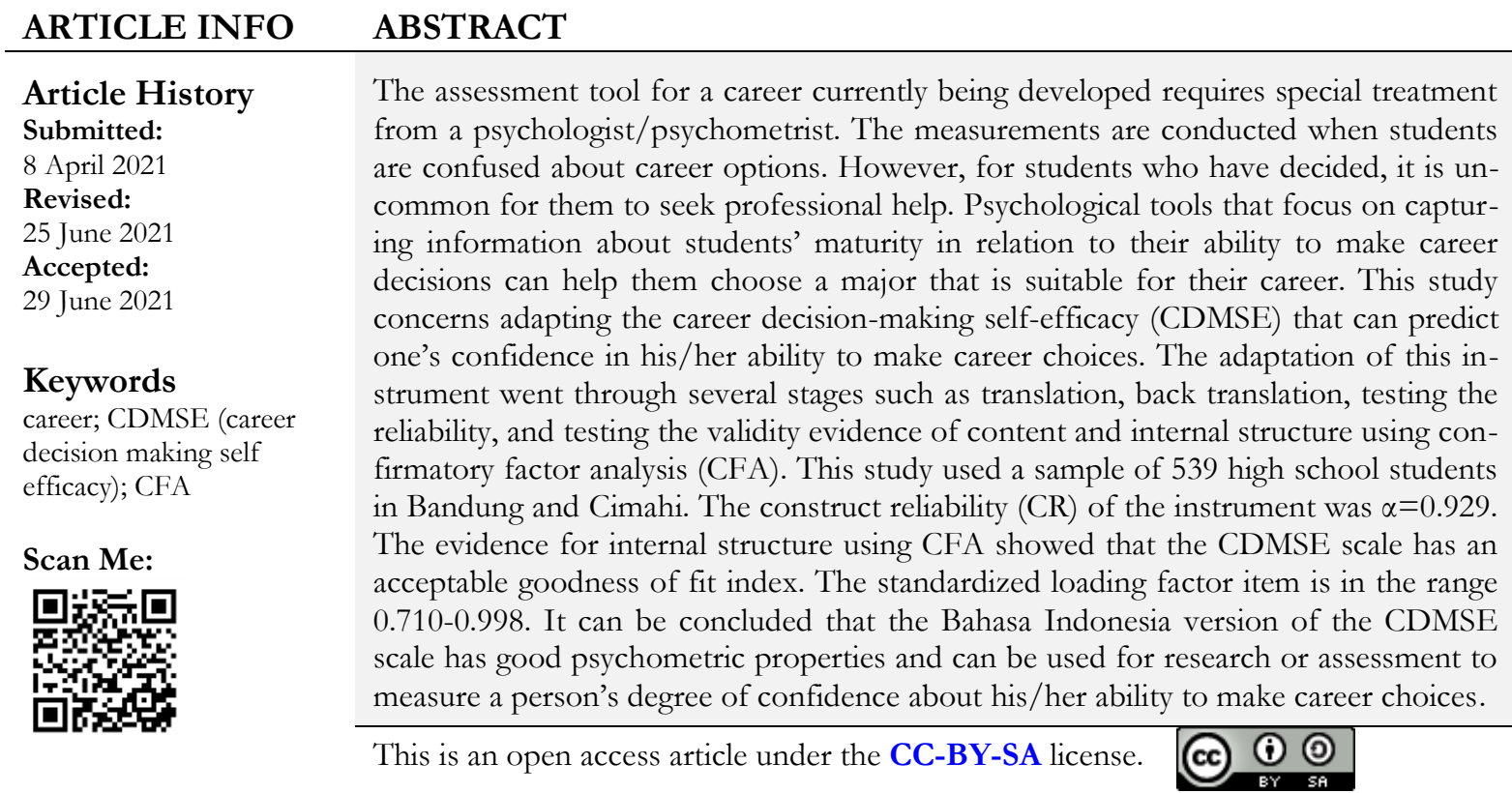

How to cite:

Purnama, C., \& Ernawati, L. (2021). A psychometric evaluation of the career decision making self-efficacy scale. Jurnal Penelitian dan Evaluasi Pendidikan, 25(1), 77-87. doi:https://doi.org/10.21831/pep.v25i1.39960

\section{INTRODUCTION}

Senior high school students have an age range between 15-19 years so that with this age range, they can be categorized into adolescence. Adolescence is a period where a person begins to be faced with a lot of situations where they have to choose. In this period, one of the development tasks was to choose and prepare to carry out a job (Hurlock, 1972). According to Seligman (1994), at approximately 17 years old, teens realized that they are responsible for his career planning. In adolescence, career development runs along with getting older and experiencing dynamics that are important in the school (Seligman, 1994). Senior high school students are in the period to determine a major in higher education to achieve the desired career. Adolescents are in the phase of self-determination. They are required to develop their selfidentity and make decisions in accordance with environmental demands (Lewis, 1981). During this period, adolescents are expected to know and realize the need to make career decisions, understand their potential, be aware of their interests and talents, measure their own abilities, and identify suitable job opportunities (Walsh et al., 2000).

The selection of fields of work is closely related to the selection of educational programs to be pursued. The chosen area of educational programs can support their success when starting and pursuing their future careers. Thus, one must understand the demands of their choice of work (Islamadina \& Yulianti, 2017). A certain job will require special abilities, expertise, or 
skills that can be obtained through formal or informal learning. In their career development, adolescence is filled with exploration (Suryanti et al., 2011). Adolescents try to explore all the possibilities. They try to understand everything that will become their needs in facing future challenges (Super \& Super, 2001).

The current phenomenon among adolescents is that many students experience confusion when they have to choose a major and their future careers (Creed et al., 2005). There are still many cases of adolescents who choose a major in university without considering their abilities, skills, interests, talents, or personality. Most of them tend to choose majors for prestige, following peers, the trends of professions, job popularity, income, certain figures, and even their parents, and some are because of their parent's wishes.

Thus, determining the majors in higher education and future careers at the end of high school becomes an important moment. The decision to make and plan career choices supports the individual's success in the future life. Their understanding of the type of career, the field of work, interests, and talents is important before deciding which career to pursue. Students who have a strong career maturity can make decisions steadily, while those with low career maturity will experience confusion and have no clear career plan. Regarding this, many students seek help from school counselors, teachers, career consultants, and even educational psychologists to help them and provide insight into their potential to avoid mistakes in choosing a major and establishing a career. One method to see an individual's maturity degree in determining the career is using psychological assessment tools. Currently, many psychological assessment tools can measure this to help students be optimal in determining careers. One such measure is Career Decision Making Self Efficacy (henceforth CDMSE) (Betz et al., 1996).

CDMSE scale was developed by Taylor and Betz in 1983 consisting of five dimensions, namely, career choice competencies in the areas of goal setting (GS), gathering occupational information (GI), problem-solving (PS), planning (PL), and also self-appraisal (SA) (Betz et al., 1996). From the five dimensions, 50 items were compiled. Each dimension is represented by ten statements. In 1996, the instrument was revised by Betz, Klein, and Taylor to only 25 items. The statement items are selected from the best five statements from each dimension (Betz et al., 1996). CDMSE are self-report using Likert scale with five options, namely strongly agree, agree, neutral, disagree, and strongly disagree.

Observing the CDMSE aspects, this measurement tool will greatly assist education counselors, counseling teachers, career consultants, and educational psychologists in assessing and predicting the right career prospect for students in universities, helping plan, and choosing a career in the future. Measuring instruments can be used to capture information about students, especially the suitability between individual characteristics and the desired career choice.

One of the challenges that sometimes surge is when there is a mismatch of the items used in the instruments made internationally when it is used in Indonesia. The incompatibility of the context of language, culture, or even the meaning of the term can be misinterpreted, so it is necessary to re-research and adapt the assessment tool to Indonesia's cultures. The purpose of adapting this measuring instrument is to obtain a CDMSE measuring instrument in accordance with Indonesian culture and the provisions of psychometric rules. The adaptation focuses on language, terms, diction, wording, scaling, and norm. Besides, by re-conducting research and adapting the instruments, it is hoped that items or statements obtained are in line with the culture of students in Indonesia and the validity, reliability, and norms to interpret the results of the scores of these students.

\section{RESEARCH METHOD}

Data collection for testing the CDMSE instrument was carried out online using the Google Form involving 539 high school students in Bandung and Cimahi. In detail, a descripttion of the respondents participating in this CDMSE instrument testing is shown in Table 1. 
79 - Chandra Yudistira Purnama \& Linda Ernawati

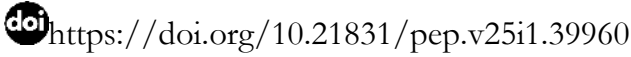

Table 1. The Description of the Respondents

\begin{tabular}{llc}
\hline \multicolumn{1}{c}{ Category } & N = 539 \\
\hline Gender & \\
& Male & 219 students \\
& Female & 320 students \\
Age & & \\
& 17 years old & 489 students \\
& 18 years old & 50 students \\
\hline
\end{tabular}

Based on the demographic description in Table 1, respondents who participated in the testing of the CDMSE instrument were dominated by female participants, with a total of 320 respondents $(59 \%)$ and 219 men (41\%). The age of respondents was dominated by students aged 17 years old with a total of 489 respondents $(90.7 \%)$, and aged 18 years old, with total of 50 respondents $(9.3 \%)$, and the mean age of the respondents was 17.09 years old $(\mathrm{SD}=0.29)$.

\section{Procedure}

The procedure of adaptation CDMSE scale begins with the process of translating a foreign language (English) into Bahasa and back translating it from Indonesian to a foreign language (English) (explained at the translation stage). After completing the translation process and being approved to proceed to the next stage, the next step is testing instruments CDMSE using statistical methods. The process carried out to obtain the statistical analysis results is by distributing online questionnaires to respondent high school students in Bandung and Cimahi. After the data was obtained, and then continued by analyzing the reliability coefficient of the measuring instrument and evidence of validity based on the internal structure using confirmatory factor analysis. The stages of adaptation to the CDMSE scale and its data processing are elaborated as follows.

\section{Stage 1: The Career Decision Making Self Efficacy Scale Translation Process}

In the first stage, the researchers' initial step was to translate the instrument from English to Bahasa Indonesia. This stage refers to the process of adapting assessment tools based on the guidelines from the International Test Committee (ITC) guidelines for translating and adapting tests (International Test Commission, 2016). The process of translating CDMSE in English into Bahasa Indonesia was carried out by four people separately. The first and second translators are professional translators who have a bachelor's degree in English literature and work as English teachers. The third and fourth translators are psychologists who have experience constructing psychological assessment tools for both academic and practical needs.

The second step was done after obtaining the translation from the four translators. The translators and researchers discussed, reviewed, and made revisions to the translation results. The final result in the second stage was to obtain a Bahasa Indonesia version of the CDMSE draft. In the third step, the initial manuscript of the Bahasa Indonesia version of the CDMSE was re-translated into English by three professional translators. Two translators work as English teachers in high school, and as professional translators, another person works as a teacher and translator at the English Language Course Institute. The results of the re-translation into English were checked for their suitability in meaning by comparing the CDMSE translation results from Bahasa Indonesia to English with the original English version of the CDMSE assessment tool. The wording of the questionnaire sentences in Bahasa Indonesia that did not match or have different meanings from the English version was corrected and revised again to get the appropriate and relevant words. Next, in the fourth stage, the Bahasa Indonesia version of the CDMSE manuscript, which was revised and adjusted based on the input from the re-translation process, was submitted to four experts to get a review of the clarity and appro- 
priateness of conceptualization the aspects being measured. The three experts involved in reviewing the Bahasa Indonesia version of the CDMSE manuscript were lecturers at the Faculty of Psychology, Universitas Achmad Yani (henceforth UNJANI), who had experience compiling measurement tools in psychology and teaching career development courses. Meanwhile, one other person was a psychology doctoral student at the Faculty of Psychology, Universitas Padjajaran Bandung. The four experts reviewed, provided input, and corrected the wording of the translated items on the Bahasa Indonesia version of the CDMSE assessment tool. The experts were given attachments of the original English version of the CDMSE instrument, the translation result from English to Bahasa Indonesia, the CDMSE manuscript agreed to be retranslated into English, the results of the re-translation from Bahasa Indonesia to English, and the Bahasa Indonesia version of the CDMSE manuscript that has been adjusted. After the experts gave suggestions, comments, input, and corrections to the less relevant or inappropriate items, the researchers made improvements to the wording of the items. These improvements were discussed again and were followed up to get the final manuscript of the Bahasa Indonesia version CDMSE instrument.

In the fifth stage, the Bahasa Indonesia version of the CDMSE final manuscript was distributed to 20 students of the Faculty of Psychology UNJANI to be tested for its readability. This stage is to get valid evidence based on test responses from the subject. The process done with students was to read together with the Bahasa Indonesia version of the CDMSE final script with a loud speaks, then asked for their explanation and confirmed the understanding of each student on each item in the Bahasa Indonesia version of the CDMSE manuscript. After confirmation of the students' readability and comprehensiveness, the Bahasa Indonesia version of the CDMSE final manuscript was converted into a digital/online version using the Google Form. Then, the Bahasa Indonesia version of the CDMSE scale that has been converted into an online version was distributed to students in Bandung and Cimahi through the counseling teachers in each school. During the one week of data collection, 539 high school students filled the Google Form.

\section{Stage 2: Reliability Testing and Model Testing of Carrer Decision Making Self Efficacy Scale}

The second stage was done to gain the reliability coefficient of the assessment tool using construct reliability (CR), average variance extracted (AVE), and testing the internal structure of CDMSE using confirmatory factor analysis (CFA). Data processing for testing the measurement tools (reliability test and validity evidence) was done using JASP 0.14.1 and Lisrel. This CDMSE scale consists of five dimensions (GI, SA, GS, PL, and PS), and each dimension consists of five items. Thus, the total number of items in this instrument is 25 items.

The data collection to obtain reliability values and validity evidence of the internal structure involved 539 high school students in Bandung and Cimahi. The CDMSE instrument that had been translated and approved through an expert review was compiled into an online questionnaire using the Google Form. The link to the questionnaire was sent to the counseling teachers in each school and distributed to students. Within one week, 539 respondents submitted the answers to be used in the data processing to test reliability and obtain valid internal structure evidence.

\section{Data Analysis}

The researchers used the JASP version 0.14, Lisrel program, and Statcal to process the data and get a composite reliability score and validity evidence from the CDMSE scale. Composite Reliability is a reliability coefficient that can be used for multidimensional measures (Heise \& Bohrnstedt, 1970), and confirmatory factor analysis is used to confirm whether the indicator variables can be used to confirm a factor (Ferdinand, 2011). 


\section{FINDINGS AND DISCUSSION}

\section{Reliability Test and Item Analysis of Carrer Decision Making Self Efficacy Scale}

Data processing for the reliability test of the CDMSE instrument was carried out using Microsoft Excel 2019, JASP version 0.14, and Statcal. Reliability can be expressed as the internal consistency of an instrument that can be measured based on the level of item homogeneity. Hair et al. (2010) explain that the reliability test in the CFA analysis includes the construct reliability (CR) and variance extracted (AVE). Hair et al. (2010) state that the CR value $\geq 0.7$ is good reliability, while the CR value between 0.6 and 0.7 is acceptable reliability, with a note that the indicator has a factor load that matches the criteria. Internal consistency can also be measured using the Average Variance Extracted (AVE) estimate. The recommended AVE value is $>0.5$ (Hair et al., 2010).

Table 2. Construct Reliability (CR) and Average Variance Extracted (AVE)

\begin{tabular}{lcc}
\hline \multicolumn{1}{c}{ Variable } & CR & AVE \\
\hline Gathering of Information & 0.84 & 0.51 \\
Self Appraisal & 0.83 & 0.51 \\
Goal Selection & 0.86 & 0.55 \\
Planning & 0.83 & 0.53 \\
Problem Solving & 0.89 & 0.63 \\
CDMSE & 0.97 & 0.88 \\
\hline
\end{tabular}

Source: Statcal

Table 3. Frequentist Individual Item Reliability Statistics

\begin{tabular}{ccccccc}
\hline & If Item Dropped & & & \multicolumn{3}{c}{ If Item Dropped } \\
\cline { 1 - 2 } \cline { 5 - 6 } Item & McDonald's $\omega$ & $\begin{array}{c}\text { Item-Rest } \\
\text { Correlation }\end{array}$ & & Item & McDonald's $\boldsymbol{~}$ & $\begin{array}{c}\text { Item-Rest } \\
\text { Correlation }\end{array}$ \\
\cline { 1 - 2 } \cline { 5 - 6 } GI 1 & 0.957 & 0.575 & & GS 4 & 0.956 & 0.670 \\
GI 2 & 0.956 & 0.644 & & GS 5 & 0.955 & 0.745 \\
GI 3 & 0.955 & 0.747 & & PL 1 & 0.956 & 0.640 \\
GI 4 & 0.955 & 0.708 & & PL 2 & 0.956 & 0.652 \\
GI 5 & 0.956 & 0.682 & & PL 3 & 0.956 & 0.622 \\
SA 1 & 0.956 & 0.686 & & PL 4 & 0.957 & 0.602 \\
SA 2 & 0.956 & 0.632 & & PL 5 & 0.956 & 0.697 \\
SA 3 & 0.955 & 0.700 & & PS 1 & 0.955 & 0.730 \\
SA 4 & 0.956 & 0.608 & & PS 2 & 0.955 & 0.777 \\
SA 5 & 0.956 & 0.632 & & PS 3 & 0.955 & 0.757 \\
GS 1 & 0.956 & 0.658 & & PS 4 & 0.956 & 0.672 \\
GS 2 & 0.955 & 0.746 & PS 5 & 0.956 & 0.685 \\
GS 3 & 0.955 & 0.711 & & & \\
\hline
\end{tabular}

Source: Goss-Sampson (2018). JASP (Version 0.14.1) [Computer software]

Table 2 shows the construct reliability (CR) and average extracted variance (AVE), while Table 3 informs about item-rest correlation. Table 2 depicts the results of data processing for the reliability test CDMSE. It shows that the CR value for the CDMSE instrument is 0.97. An assessment instrument is said to be reliable if the CR coefficient value is greater than $0.7(\alpha \geq$ 0.7) (Hair et al., 2019), so the CDMSE instrument adapted into Bahasa Indonesia is reliable. Table 3 provides information about item analysis to see the quality of items on the CDMSE scale. The data shows the quality of items on the CDMSE scale, whether they have good items or not, by looking at the scores in the item-rest correlation column. An item is good if it has an item-rest correlation value greater than 0.3 (Pallant, 2011). The test results on the item quality obtained the item-rest correlation coefficient value in the range of 0.575 to 0.777 . 


\section{Validity Evidence}

The examination of the validity evidence on the CDMSE scale used guidelines from AERA, that is, evidence based on test content, evidence based on test responses, evidence based on internal structure, evidence based on relation to other variables, and evidence based on consequences of the testing (American Educational Research Association (AERA) et al., 2014). Of the five pieces of evidence validity, the researchers only carried out three pieces of evidence. First, it was evidence-based on test content obtained from the subject matter expert (henceforth SME). Second, it was based on evidence-based test responses obtained from the readability of students and lecturers. Lastly, the third was evidence based on the internal structure using confirmatory factor analysis.

In obtaining valid evidence based on test content, the researchers asked the SME to assess whether the items in the CDMSE scale were relevant and in accordance with the construct. The SMEs gave a score of 1 for items that were considered strongly irrelevant, a score of 2 for items considered irrelevant, a score of 3 for items considered fair enough relevant, a score of 4 for items considered relevant, and a score of 5 for items that were considered strongly relevant. The context of the assessment is viewed from the suitability of the language, clarity of the wording, and the suitability of the meaning of the translated sentence. The results of the SME assessment were processed with Aiken's V formula (Aiken, 1985). The Aiken's V value for all CDMSE items ranged from 0.83 to 0.92. Hence, the CDMSE scale can be used to measure confidence in making career decisions.

In the process of obtaining valid evidence in the form of evidence based on test responses, it is obtained through the readability of 20 respondents. Based on the responses from students, the items in the CDMSE scale can be understood well.

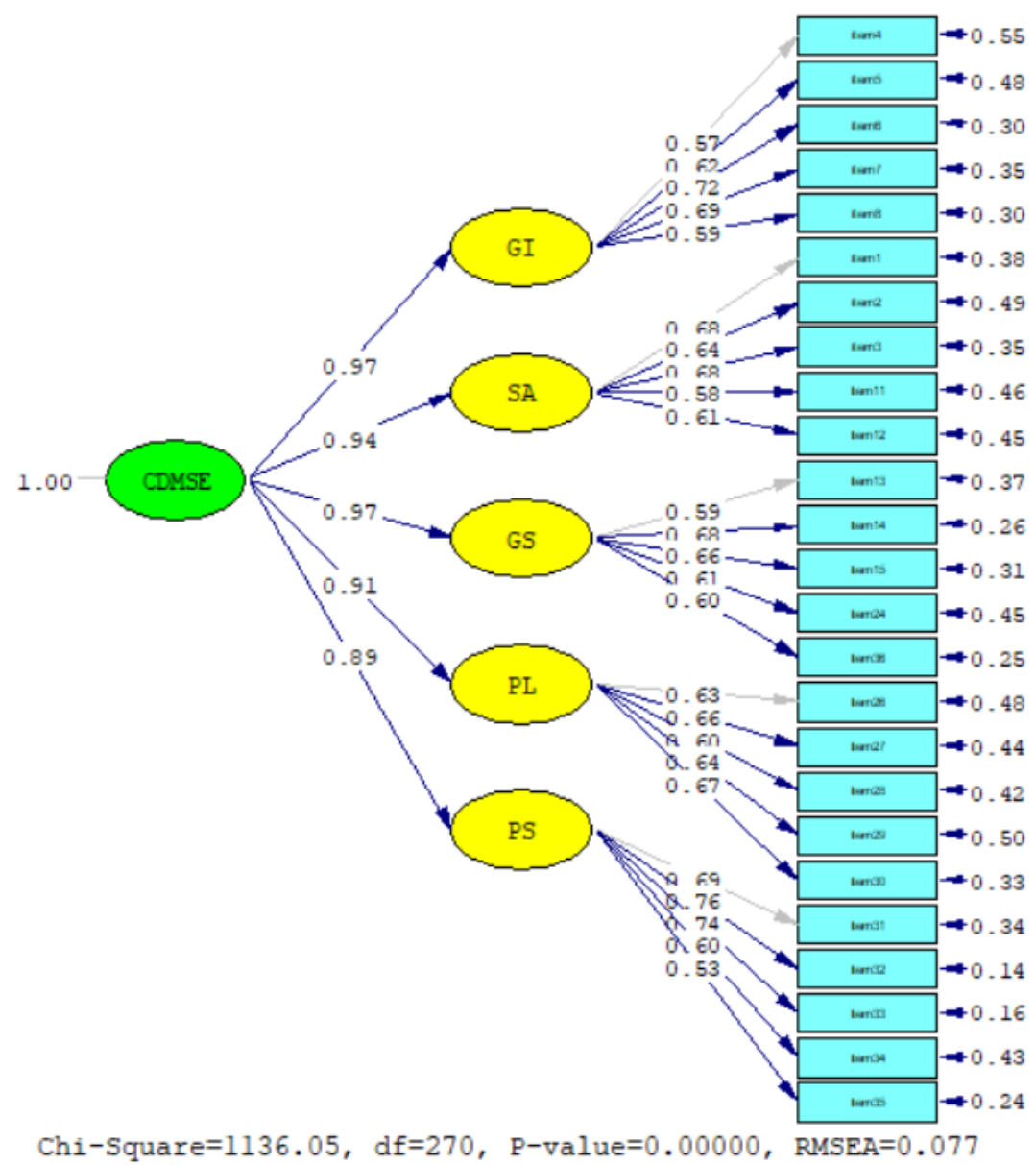

Figure 1. The Results of the Model Fit Test 
The next evidence is evidence based on the internal structure using confirmatory factor analysis (CFA). The benchmarks used to interpret the suitability of the model in this study refers to $\mathrm{Hu}$ and Bentler who recommended four parameters, namely, the Chi-Square Test pvalue $\geq 0.05$; the Root Mean Square Error of Approximation (RMSEA) $\leq 0.08$; Comparative Fit Index $(\mathrm{CFI}) \geq 0.95$; and Standardized Root Mean Square Residual (SRMR) $\leq 0.08$ (Hu \& Bentler, 1999). Meeting these criteria means that the instrument meets the appropriate model criteria. Figure 1 shows the results of the model fit test using CFA.

Table 4. The Goodness of Fit Indices from the CDMSE Model

\begin{tabular}{|c|c|c|c|c|c|}
\hline Category & Parameter Fit & Output & Cut Off & Criteria & Information \\
\hline \multirow[t]{4}{*}{ Absolute Fit } & Chi square p-value & $<0.000$ & $>0.05$ & Good Fit & Not Fit \\
\hline & GFI & 0.86 & $\begin{array}{c}\geq 0.90 \\
0.80-0.89\end{array}$ & $\begin{array}{c}\text { Good Fit } \\
\text { Marginal Fit }\end{array}$ & Marginal Fit \\
\hline & RMSEA & 0.07 & $\begin{array}{c}\leq 0.08 \\
0.08-0.10\end{array}$ & $\begin{array}{c}\text { Good Fit } \\
\text { Marginal Fit }\end{array}$ & Good Fit \\
\hline & SRMR & 0.048 & $\begin{array}{c}<0.08 \\
0.08-0.10\end{array}$ & $\begin{array}{c}\text { Good Fit } \\
\text { Marginal Fit }\end{array}$ & Good Fit \\
\hline \multirow[t]{4}{*}{ Incrimental Fit } & AGFI & 0.83 & $\begin{array}{c}\geq 0.90 \\
0.80-0.89\end{array}$ & $\begin{array}{c}\text { Good Fit } \\
\text { Marginal Fit }\end{array}$ & Marginal Fit \\
\hline & NFI & 0.97 & $\begin{array}{c}\geq 0.90 \\
0.80-0.89\end{array}$ & $\begin{array}{c}\text { Good Fit } \\
\text { Marginal Fit }\end{array}$ & Good Fit \\
\hline & IFI & 0.98 & $\begin{array}{c}\geq 0.90 \\
0.80-0.89\end{array}$ & $\begin{array}{c}\text { Good Fit } \\
\text { Marginal Fit }\end{array}$ & Good Fit \\
\hline & CFI & 0.98 & $\begin{array}{c}\geq 0.90 \\
0.80-0.89\end{array}$ & $\begin{array}{c}\text { Good Fit } \\
\text { Marginal Fit }\end{array}$ & Good Fit \\
\hline Parsimonious Fit & PNFI & 0.87 & $>0.5$ & Good Fit & Good Fit \\
\hline
\end{tabular}

Based on the goodness of fit indices test presented in Table 4, there are six that meet the criteria, namely, RMSEA of $0.07 \leq 0.08$, SRMR of $0.048 \leq 0.08$, NFI of $0.97 \geq 0.90$, IFI of $0.98 \geq 0.90$, CFI of $0.98 \geq 0.90$ and PNFI $0.87 \geq 0.05$. There are two criteria that meet marginal fit criteria: GFI of $0.85 \leq 0.90$, AGFI of $0.83 \leq 0.90$, and one criterion that cannot be fulfilled is the chi-squared test because the $\mathrm{p}$-value obtained $<0.001$. The Chi-Square value is the traditional measure to evaluate the suitability of the overall model (Hu \& Bentler, 1999). A good fit model will give insignificant results at the 0.05 threshold (Barrett, 2007). The Chisquare index is the most used index to check the accuracy of the model. However, this index is strongly affected by the sample size (Bergh, 2015). If the sample is too small, the trend will be insignificant, while the trend will be significant if the sample is too large. Thus, the Chisquare almost certainly rejects the model if a large number of samples are used. In this study, the sample size used was 539 .

Based on the test results of the fit model, from nine proposed parameters, there are eight that meet the criteria, six criteria (RMSEA, SRMR, NFI, IFI, CFI, and PNFI) for a good fit, and two criteria (GFI and AGFI) for marginal fit, while one criterion (Chi-square) does not meet the criteria. Therefore, the researchers tried to modify the model to get a better model. Attempts to modify the model are by deleting items. The results of model testing after modification are shown in Figure 2.

Based on the modification results, ten items were obtained that matched the model, including GI3, GI4, SA1, SA2, GS2, GS3, PL4, PL5, PS2, and PS5. Then, the results of the goodness of fit of indices test are shown in Table 5. From Table 5, the model is fit. There is no significant difference between the model ideal with the proposed model based on measurements. All parameters of goodness of fit indices have also been according to the criteria set for 
obtaining a model fit. Thus, the final model is already fit, which means the model proposed fits the empirical data. The complete model and loading factor of each item in the final model can be seen in Figure 2.

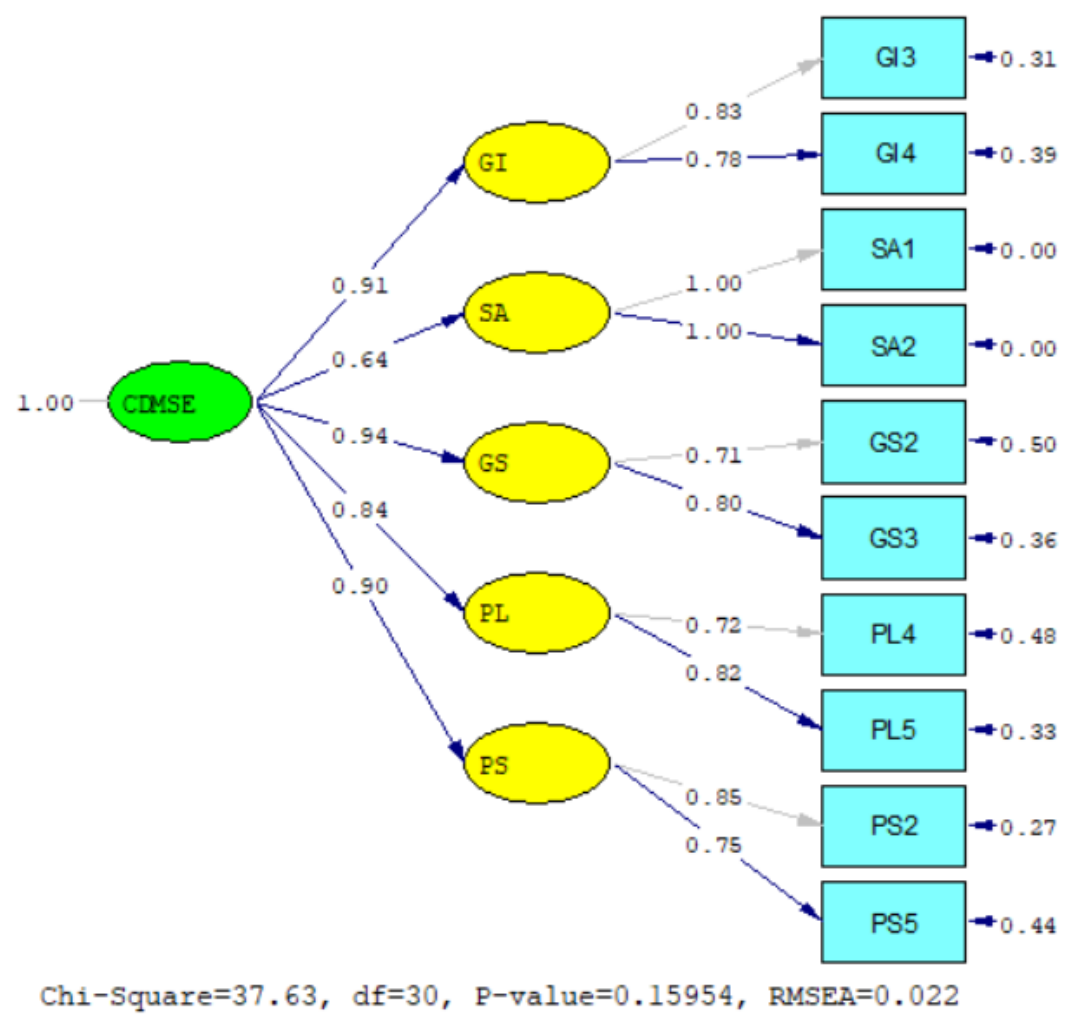

Figure 2. The Results of the Model Fit Test

Table 5. The Goodness of Fit Indices from the CDMSE Model

\begin{tabular}{|c|c|c|c|c|c|}
\hline Category & Parameter Fit & Output & Cut Off & Criteria & Information \\
\hline \multirow[t]{4}{*}{ Absolute Fit } & Chi square $\mathrm{p}$-value & 0.159 & $>0.05$ & Good Fit & Good Fit \\
\hline & GFI & 0.99 & $\begin{array}{c}\geq 0.90 \\
0.80-0.89\end{array}$ & $\begin{array}{c}\text { Good Fit } \\
\text { Marginal Fit }\end{array}$ & Good Fit \\
\hline & RMSEA & 0.022 & $\begin{array}{c}\leq 0.08 \\
0.08-0.10\end{array}$ & $\begin{array}{c}\text { Good Fit } \\
\text { Marginal Fit }\end{array}$ & Good Fit \\
\hline & SRMR & 0.020 & $\begin{array}{c}<0.08 \\
0.08-0.10\end{array}$ & $\begin{array}{c}\text { Good Fit } \\
\text { Marginal Fit }\end{array}$ & Good Fit \\
\hline \multirow[t]{4}{*}{ Incrimental Fit } & AGFI & 0.97 & $\begin{array}{c}\geq 0.90 \\
0.80-0.89\end{array}$ & $\begin{array}{c}\text { Good Fit } \\
\text { Marginal Fit }\end{array}$ & Good Fit \\
\hline & NFI & 0.99 & $\begin{array}{c}\geq 0.90 \\
0.80-0.89\end{array}$ & $\begin{array}{c}\text { Good Fit } \\
\text { Marginal Fit }\end{array}$ & Good Fit \\
\hline & IFI & 0.99 & $\begin{array}{c}\geq 0.90 \\
0.80-0.89\end{array}$ & $\begin{array}{c}\text { Good Fit } \\
\text { Marginal Fit }\end{array}$ & Good Fit \\
\hline & CFI & 0.99 & $\begin{array}{c}\geq 0.90 \\
0.80-0.89\end{array}$ & $\begin{array}{c}\text { Good Fit } \\
\text { Marginal Fit }\end{array}$ & Good Fit \\
\hline Parsimonious Fit & PNFI & 0.66 & $>0.5$ & Good Fit & Good Fit \\
\hline
\end{tabular}

Source: Ghozali \& Fuad (2005)

The next part examines the results of the factor loading analysis of the CDMSE assessment tool. The test results can be seen in Table 6 . The criteria for an item to be said to have a good factor loading is when the factor loading value is $\geq 0.5$ (Hair et al., 2019). 
85 - Chandra Yudistira Purnama \& Linda Ernawati

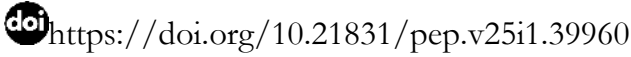

Table 6. Factor Loading of CDMSE

\begin{tabular}{ccc}
\hline Factor & Indicator & Std. Est. (all) \\
\hline Gathering of Information & GI 3 & 0.827 \\
Self Appraisal & GI 4 & 0.782 \\
& SA 1 & 0.999 \\
Goal Selection & SA 2 & 0.998 \\
& GS 2 & 0.710 \\
Planning & GS 3 & 0.794 \\
Problem Solving & PL 4 & 0.720 \\
& PL 5 & 0.823 \\
& PS 2 & 0.856 \\
& PS 5 & 0.750 \\
\hline
\end{tabular}

Based on the results of the standardized loading factors, the CDMSE items and each dimension have a factor loading value above 0.5 with a range between $0.710-0.998$. This shows that the quality of the items is classified as good.

After testing the model and standardized loading factors, a reliability test was then carried out. Reliability testing in CFA includes the construct reliability (CR) and variance extracted (AVE). The results of the reliability test are shown in Table 7 and Table 8.

Table 7. Construct Reliability (CR) and Average Variance Extracted (AVE)

\begin{tabular}{lcc}
\hline \multicolumn{1}{c}{ Variable } & CR & AVE \\
\hline Gathering of Information & 0.786 & 0.648 \\
Self Appraisal & 0.998 & 0.997 \\
Goal Selection & 0.723 & 0.568 \\
Planning & 0.747 & 0.597 \\
Problem Solving & 0.786 & 0.648 \\
CDMSE & 0.929 & 0.726 \\
\hline
\end{tabular}

Source: Statcal

Table 8. Frequentist Individual Item Reliability Statistics

\begin{tabular}{ccc}
\hline \multicolumn{3}{c}{ If Item Dropped } \\
\hline Item & McDonald's $\boldsymbol{\omega}$ & Item-Rest Correlation \\
\hline GI3 & 0.896 & 0.714 \\
GI4 & 0.898 & 0.683 \\
SA1 & 0.898 & 0.688 \\
SA2 & 0.898 & 0.687 \\
GS2 & 0.902 & 0.605 \\
GS3 & 0.897 & 0.701 \\
PL4 & 0.906 & 0.576 \\
PL5 & 0.900 & 0.663 \\
PS2 & 0.828 & 0.729 \\
PS5 & 0.901 & 0.640 \\
\hline
\end{tabular}

Based on Table 7, the CR value for the CDMSE instrument after modification is 0.929. Thus, based on the test results, the CDMSE instrument adapted into Bahasa Indonesia is reliable. Table 8 shows that the test results on the item quality obtained the item-rest correlation coefficient value from 0.576 to 0.729 .

The results of this study were conducted on a sample of students from Bandung and Cimahi. This is one of the limitations of this study because it does not involve many students from other cities in Indonesia. Therefore, for further research, it is recommended to expand the coverage of student participants from various cities and regions in Indonesia and increase the sample size to obtain a more fit model with a larger scale of participants. 


$$
\begin{aligned}
& 86 \text { - Chandra Yudistira Purnama \& Linda Ernawati } \\
& \text { doi }_{\text {https://doi.org/10.21831/pep.v25i1.39960 }}
\end{aligned}
$$

\section{CONCLUSION}

Based on the findings of the research regarding the psychometric analysis of the adaptation of the CDMSE scale into Bahasa Indonesia, some conclusions can be drawn, as follows. (1) The CDMSE scale test results can be said reliable. It means that it can consistently measure an individual's level of self-confidence regarding his or her ability to make career choices. (2) The CDMSE scale with five dimensions has a model that fits the original construct based on Goodness of Fit Indices. (3) The test results showed good item quality and can accurately measure the dimensions of one's CDMSE. Thus, these items can measure the level of an individual's self-confidence regarding his or her ability to make career choices. (4) The CDMSE scale can be used to measure a person's CDMSE scale and as an additional variety of instruments related to career assessment tools.

\section{ACKNOWLEDGMENT}

The authors express their heartfelt gratitude to the Institute of Research and Community Service (LPPM) of Universitas Jenderal Achmad Yani for supporting and funding this research.

\section{REFERENCES}

Aiken, L. R. (1985). Three coefficients for analyzing the reliability and validity of ratings. Educational and Psychological Measurement, 45(1), 131-142. https://doi.org/10.1177/0013164485451012

American Educational Research Association (AERA), American Psychological Association (APA), \& National Council on Measurement in Education (NCME). (2014). Standards for educational and psychological testing. American Educational Research Association (AERA), American Psychological Association (APA), and National Council on Measurement in Education (NCME).

Barrett, P. (2007). Structural equation modelling: Adjudging model fit. Personality and Individual Differences, 42(5), 815-824. https:/ / doi.org/10.1016/j.paid.2006.09.018

Bergh, D. (2015). Chi-squared test of fit and sample size - A comparison between a random sample approach and a Chi-square value adjustment method. Journal of Applied Measurement, 16(2), 204-217.

Betz, N. E., Klein, K. L., \& Taylor, K. M. (1996). Evaluation of a short form of the career decision-making self-efficacy scale. Journal of Career Assessment, 4(1), 47-57. https://doi.org/10.1177/106907279600400103

Creed, P., Prideaux, L.-A., \& Patton, W. (2005). Antecedents and consequences of career decisional states in adolescence. Journal of Vocational Behavior, 67(3), 397-412. https://doi.org/10.1016/j.jvb.2004.08.008

Ferdinand, A. T. (2011). Metode penelitian manajemen: Pedoman penelitian untuk penulisan skripsi, thesis, dan disertasi Ilmu Manajemen. Universitas Diponegoro.

Ghozali, I., \& Fuad, F. (2005). Structural equation modeling: Teori, konsep, \& aplikasi dengan program Lisrel 8.54. Universitas Diponegoro.

Goss-Sampson, M. A. (2018). Statistical analysis in JASP: A guide for students. https://static.jaspstats.org/Statistical Analysis in JASP - A Students Guide v2.pdf

Hair, J. F., Babin, B. J., Anderson, R. E., \& Black, W. C. (2019). Multivariate data analysis (8th ed.). Cengage Learning. 
Hair, J. F., Black, W. C., Babin, B. J., \& Anderson, R. E. (2010). Multivariate data analysis. Pearson.

Heise, D. R., \& Bohrnstedt, G. W. (1970). Validity, invalidity, and reliability. Sociological Methodology, 2, 104-129. https://doi.org/10.2307/270785

Hu, L., \& Bentler, P. M. (1999). Cutoff criteria for fit indexes in covariance structure analysis: Conventional criteria versus new alternatives. Structural Equation Modeling: A Multidisciplinary Journal, 6(1), 1-55. https://doi.org/10.1080/10705519909540118

Hurlock, E. B. (1972). Child development (McGraw-Hill series in psychology). McGraw-Hill.

International Test Commission. (2016). The ITC guidelines for translating and adapting tests (2nd ed.). International Test Commission (ITC). https://www.intestcom.org/files/guideline_test_adaptation_2ed.pdf

Islamadina, E. F., \& Yulianti, A. (2017). Persepsi terhadap dukungan orangtua dan kesulitan pengambilan keputusan karir pada remaja. Jurnal Psikologi, 12(1), 33-38. https://doi.org/10.24014/jp.v12i1.3006

Lewis, C. C. (1981). How adolescents approach decisions: Changes over grades seven to twelve and policy implications. Child Development, 52(2), 538-544. https://doi.org/10.2307/1129172

Pallant, J. (2011). SPSS survival manual: A step by step guide to data analysis using IBM SPSS. Open University Press.

Seligman, L. (1994). Developmental career counseling and assessment (2nd ed.). SAGE Publication.

Super, C. M., \& Super, D. E. (2001). Opportunities in psychology careers. McGraw-Hill.

Suryanti, R., Yusuf, M., \& Priyatama, A. N. (2011). Hubungan antara Locus of Control internal dan konsep diri dengan kematangan karir pada siswa kelas XI SMK Negeri 2 Surakarta. Wacana: Jurnal Psikologi, 3(1). https://jurnalwacana.psikologi.fk.uns.ac.id/index.php/wacana/article/view/46

Walsh, W. B., Bingham, R. P., Brown, M. T., Ward, C. M., \& Osipow, S. H. (Eds.). (2000). Career counseling for African Americans. Lawrence Erlbaum Associates. 